\title{
Evaluation of research initiatives on the problem of reducing the aviation transport noise rate in accordance with the tasks of Flightpath 2050 goal 9
}

\author{
Sergiy Dmytriyev ${ }^{1, *}$, Vasyl Loginov ${ }^{2}$, Mykhailo Mitrakhovich ${ }^{1}$, and Ekaterina Doroshenko ${ }^{3}$ \\ ${ }^{1}$ State Enterprise "Ivchenko-Progress", 2, Ivanova street, Zaporozhye, 69068, Ukraine \\ ${ }^{2}$ Joint Stock Company "FED", 132, Sumskaya street, Kharkov, 61023, Ukraine \\ ${ }^{3}$ National Aviation University, 1, Komarova avenue, Kyev, 03058, Ukraine
}

\begin{abstract}
The technical solutions to reduce noise level in engines of power plants were reviewed in the work. The review on priority of the projects directed to solve the problems of air vehicle acoustic reduction proceeding from evaluation of the main requirements of Strategic Research and Innovation Agenda of ACARE was presented. One of the main directions of research within Flightpath 2050 (goal 9) is a rational integration of airframe elements and power plant. The evaluation results of research initiatives as for the problem to reduce noise of GTE were substantiated according to program Flightpath 2050. On the grounds of the analytical data it was estimated that electrical airplanes and Open Rotor engines characterized by higher efficiency compared to bypass engines with a high bypass ratio $(\mathrm{m}=50 \ldots 70)$ would further develop to a new level by 2050 . It was marked that the aircraft with a distributed electrical power plant could essentially influence the solution of the problem to reduce noise of power plants in future.
\end{abstract}

\section{Introduction}

The number of aviation operations is constantly growing in the world against the background of global challenges related to climatic change, atmospheric contamination and reduction in volumes of non-renewable energy resources. It is commonly known that modern civil aviation causes adverse impact on environment. The major factors of the aircraft $(\mathrm{A} / \mathrm{C})$ adverse impact are: noise, pollutant emissions, electromagnetic interference and acoustic shock. At present the most important factors of the adverse impact of $\mathrm{A} / \mathrm{C}$ operation within airport are aviation noise and pollutant emissions from the engine. Increase in operating rate of civil $\mathrm{A} / \mathrm{C}$ (increase in number of takeoffs and landings in airports) led to round-the-clock noise influence on residential areas by aircraft takeoffs and landings. Noise negatively impacts inhabitants' health, market price of land and residence. Acoustic improvement of $\mathrm{A} / \mathrm{C}$ is one of the important requirements for modern and

* Corresponding author: s.dmytriyev@ivchenko-progress.com 
advanced $\mathrm{A} / \mathrm{C}$ and engines. Therefore reduction in aviation noise impact on environment is an important scientific and technical problem. In [1], the results of research on the Silent Aircraft Initiative program are presented. In [2], aircraft noise reduction is considered as part of the optimal integration of the power plant and the aircraft. However, the departure from the classical layout of the aircraft is likely to require an increase in reserves of gasdynamic stability. However approaches to the solution of this problem are different in various countries and depend greatly on culture, economics and policy of each country. Evolvement of progressive trends in aircraft industry encourages the search of innovative approaches to $\mathrm{A} / \mathrm{C}$ design and inculcation of optimum technical solutions. The most efficient is a comprehensive approach to the solution of this problem on the basis of implementation of design and technical activities in development of $\mathrm{A} / \mathrm{C}$ and power plants (PP), special flying technique, rational arrangement of air traffic, inculcation of construction scheduled activities in airport areas, restriction of harmful impacts near airports and monitoring of its adherence [3].

Today in civil aviation engines with a high degree of bypass are widely used. The main sources of noise in engines with a high degree of bypass, in the front hemisphere, are a fan and a compressor, in the rear hemisphere - a fan, a jet stream, a turbine and a combustion chamber. A reduction in engine noise level is provided by an increase in the bypass ratio of the engine, reduction in fan noise, optimization of cycle parameters, the use of rotors with opposite rotation, the use of sound-absorbing structures and a decrease in the level of turbulence at the fan inlet. Of interest is the development of a straightening apparatus to reduce the level of turbulence at the engine inlet, which can significantly reduce discrete and broadband noise, in addition, the use of a special design input device reduces the level of vortex noise at the fan inlet [4]. Particular attention is paid to the methods of gasdynamic impact on the flow in fans and compressors to reduce acoustic radiation in the source. It was shown in [5] that the active control of the boundary layer on the blades allows reducing significantly acoustic radiation. However, this method requires an additional supply of energy, which complicates its technical performance. In [6], an overview of jet noise reduction methods is presented. Such methods include liquid injection, the use of a tapered nozzle, the use of micro jets, and high-frequency excitation. One of the promising developments is the Open Rotor engine, such engines have high efficiency. However, acoustic characteristics require additional research and refinement. The work [7-8] analyzes the characteristics of an open rotor engine for a wide range of operating modes. It was shown in [8] that the designed engine will have higher efficiency, it is also noted that such engines have a margin in noise level of $13 \mathrm{~dB}$ relative to the requirements of Chapter 4 of the ICAO standard. The results of [9] showed that with a decrease in the diameter of the second impeller of the open rotor by $20 \%$, the acoustic emission from the interaction of the first and second RC decreases. It is evident that on the basis of introduction of advanced innovation technologies [10] it is possible to improve $\mathrm{A} / \mathrm{C}$ performance, reduce $\mathrm{A} / \mathrm{C}$ negative impact on environment, raise energy efficiency. The results of review and preliminary evaluation of the technologies readiness level as well as the market readiness and commercialization level for 15 innovations in the field of turbofan and turboprop GTE were shown in this work. Research objective of this work is a preliminary analytical estimation of prospects of achieving the aim of ACARE Flightpath 2050 (goal 9) on the basis of preliminary evaluation on feasibility of technologies, which are elaborated in the frame of research initiatives on the problem of reducing noise produced from turbofan and turboprop GTE. 


\section{Review of the literature source}

It is known that in order to achieve aims of ACARE as for "Flightpath 2050, goal 9: "In 2050 technologies and procedures available allow a 75\% reduction in $\mathrm{CO}_{2}$ emissions per passenger $\mathrm{km}$ and a $90 \%$ reduction in NOx emissions. The perceived noise of flying aircraft is reduced by $65 \%$. These are relative to the capabilities of typical new aircraft in 2000 ", the leading aviation companies of the world elaborate new engines by several programs simultaneously $[11,12]$.

The demand for increase in $\mathrm{A} / \mathrm{C}$ load-lifting capacity and its flight speed led to augmentation in power plant engine thrust, as a result acoustic power and noise level (produced by $\mathrm{A} / \mathrm{C}$ ), which essentially exceeded threshold limit values, grew abruptly. Actually in the field of aviation acoustics it was required to solve a triune problem linking aerodynamics, strength and acoustics.

Considering the significance of determining acoustic characteristics of modern and advanced engines "Ivchenko-Progress" SE (Ukraine) elaborates and improves the methods for bench tests of gas-turbine engines for conformity to ecological requirements [13]. The analysis and mathematical modelling of influence on new design solutions are undertaken to meet the allowances of chapter 4 ICAO on noise [14]. Intense acoustic loads applied to $\mathrm{A} / \mathrm{C}$ are the cause of damage in its structural elements and breakdown of the equipment. Therefore acoustic characteristics in several cases determine $\mathrm{A} / \mathrm{C}$ parameters and scheme as well as parameters and type of its power plant. When designing an aircraft, in which the noise level exceeds admissible values, an issue of finding the parameters and characteristics of an aircraft concept is solved as an inverse problem of design. Admissible noise is assumed as unit proceeding from a superposition, quoted by equipment and systems generating aviation noise. Reduction of thrust/weight ratio of the power plant should be accompanied with increase in lift-to-drag ratio of the aircraft. Evaluation of the technology readiness level of the most advanced technologies and general integration into new generation of Green Regional Aircraft (GRA) is reviewed in work [15] as a highly optimized configuration meeting the requirements for Flightpath 2050. Airplane structural features to achieve aims of ACARE: improvement of fuel efficiency, reduction of $\mathrm{CO}_{2}$ harmful/acoustic emissions are reviewed in [16]. One of the methods to reduce noise is electric aircraft with MEA (More Electric Aircraft) technology [17]. The current technology readiness (maturity) level for various objects of research can be assessed using the method of Technology Readiness Level (TRL) [18]. TRL model objectifies the evaluation of technology readiness level, simplifies for designers and customers the supervision over the course of their elaboration and selection of those ready to full extent for the system integration and inculcation into industry.

\section{Method of research}

The current level of technology readiness (maturity) for various research objects can be estimated using the TRL method. The 9-level TRL scale, compiled on the principle of "from simple to complex", developed at NASA, has become applicable to the description of technology readiness. The scale of decision points on the successful passage of TRL is: TRL 1 - Basic principles observed; TRL 2 - Technology concept formulated; TRL 3 Experimental proof of concept; TRL 4 - Technology validated in lab; TRL 5 - Technology validated in relevant environment; TRL 6 - Technology demonstrated in relevant environment; TRL 7 - System prototype demonstration in operational environment; TRL 8 - System complete and qualified; TRL 9 - Actual system proven in operational environment. The main purpose of applying the TRL concept is to assist management personnel in making decisions regarding the transition to the next stages of development or 
use of technology. The level of readiness is an indicator of the state of the development process, which allows, within the framework of a formalized scale, to assess the degree of its readiness for practical use in the development and production of innovative products and decide on whether to continue the work and successfully complete the development process. In spite of sufficiently wide prevalence of TRL method, the parameters such as organizational readiness, risks and competitive advantages, market readiness and team competence are also important to evaluate the level of technology feasibility. It is a range of issues that confirm the level of market readiness and commercialization of the CRL (Commercialization Readiness Level). Comparison of the development level of technology with market demands enables us to comprehend at what stage of development it is situated and at what distance to the market it stands. This evaluation makes possible to start shaping of technology advancement strategy [19].

Thus to make a comprehensive analytical evaluation of a design one should use the method of TRL and the method of CRL simultaneously.

Research methods: the method of technology readiness level and the method of market and commercialization readiness level are used in the work to make analytical evaluation.

Calculating tool NYSERDA (Technology \& Commercialization Readiness Level Calculator) is used as software. TRL/CRL Calculator is based on the systems developed by NASA, DOE, and ARPA-E, and has been designed specifically for ventures in the clean energy industry. Calculator has the following categories for questions: Technology, Product Development, Product Definition/Design, Competitive Landscape, Team, Go-To-Market, Manufacturing/Supply Chain. For each category, professional advisor selects the button next to the description that fits the status of product/innovation in the best way. That calculator will determine the appropriate TRL and CRL levels based on professional advisor answers.

\section{Results and discussion}

Using the above mentioned research methods and analytical procedures to evaluate technology readiness level as well as market and commercialization readiness level, the main results were obtained as for several design solutions listed below:

Projects of the USA: Fan for engine. Company Pratt \& Whitney conducted works by 2 stages on creation of the fan for engine series Pure Power Turbofan.

Noise reduction of the fan of the first generations is provided by decrease in rotational speed and by employment of a fan blade with a specific shape. Engine Pure Power PW1000G provides reduction of the noise level by $50 \ldots 75 \%$, maintaining it by $15-20 \mathrm{~dB}$ lower than the standard, which is the strictest of all existing ones (ICAO Stage 4). Results of evaluation: $\mathrm{TRL}=9, \mathrm{CRL}=9$.

The fan of the second generation. Pratt \& Whitney developments are focused on decrease in fuel consumption by $33 \%$, emissions of carbon dioxide by $60 \%$ and noise level by $32 \mathrm{~dB}$ till 2030 in reference to the level in the year 2000. The engine fan has fewer blades [20]. Results of evaluation: $\mathrm{TRL}=7, \mathrm{CRL}=4$.

Fan for engine series GEnx. New engine GEnx (General Electric Next Generation) - the family of turbofan engines, designed and manufactured by American company GE Aviation for Boeing 787 Dreamliner and Boeing 747-8. The noise reduction is provided by the upgraded shape of fan blades in terms of aero-acoustic characteristics [21]. Results of evaluation: $\mathrm{TRL}=9, \mathrm{CRL}=9$.

Projects of Great Britain. Composite fan blade designed by Rolls-Royce. Company RollsRoyce designs engines under programs Advance and Ultra Fan. The technologies inculcated make possible to reduce engine weight and raise fuel efficiency by $20 \%$ for Advance and by $25 \%$ for Ultra Fan, decrease the noise and hazardous emission level [22]. 
The fan noise is reduced due to employment of the reduction gear, improved shape of fan blades with due regard to multi-parametric optimization of aerodynamic and acoustic behavior as well as making of blades from composite materials. Therefore development of composite materials is essential within the scope of achieving the aim of program ACARE Flightpath 2050. The tests performed on a specially manufactured model showed noise reduction by $10 \mathrm{~dB}$ without any noticeable influence on aerodynamics [23]. Results of evaluation: $\mathrm{TRL}=8, \mathrm{CRL}=4$.

Projects of France. Propfan OPEN ROTOR developed by SAFRAN. Engine efficiency with a propfan OPEN ROTOR is much higher than that of the bypass turbofan engine with bypass ratio $m=50 \ldots 60$. However the application of this engine type entails the solution of the problem on rational integration of the engine and the airframe or even creation of a completely new aircraft for engines of such type. The engine of OPEN ROTOR type meets noise allowances of ICAO Chapter 4. Nevertheless at considerable strengthening of ICAO requirements this engine type demands serious upgrading on reduction of acoustic emission. The company expects that new structure will provide fuel saving by $15 \%$ compared to turbofan model LEAP-1, built by joint-venture CFM International (Safran and GE Aviation). The aim of DREAM project (Validation of Radical Engine Architecture systems) was to output completely new design of the air engine combining efficiency of turboprop and power of turbojet, but free from their drawbacks. Results of evaluation: $\mathrm{TRL}=7, \mathrm{CRL}=4$.

Fan blade designed by SAFRAN. Safran takes part in LEAP engine design, which will have high ecological rates and high economy. Within those researches company Safran designs fan blades, which will be able to ensure high acoustic efficiency. Results of evaluation: TRL $=9, C R L=9$.

Sound absorbing structure (SAS) with 3D spiral cell of Safran Nacelles. Safran Nacelles carried out researches focused on the study of complex SAS [24]. Numerical studies of acoustic characteristics were conducted along with the model physical experiment, which confirmed the studies efficiency for SAS application in nacelles of the next generation engines in order to attenuate lower frequencies. The specific shape of cells enables to reduce SAS thickness that will ensure reduction of nacelle weight. Results of evaluation: $\mathrm{TRL}=3, \mathrm{CRL}=2$.

Projects of Germany. Compressor fan blade with blowing out extra air mass into aerodynamic wake. Among the passive controls over the boundary layer it is worth noting the application of double-row and multiple-row blade rings both in stator and rotor elements. The active control over the boundary layer - blowing out extra air mass into aerodynamic wake - enables reduction of broad-band noise. The review conducted on the projects showed their high efficiency in reduction of discrete and broad-band noise. However technological accomplishment of engines applying the control over the boundary layer is rather labour intensive one. The results of researches focused on reduction of tonal noise by the method of sectional blowing of air through the trail edge are shown in the work [25]. Results of evaluation: $\mathrm{TRL}=3, \mathrm{CRL}=1$.

All-European projects. Device for noise reduction in the airframe of the aircraft with turboprop engines. Within the research scope companies SFIDA, UNINA and NOVOTECH joined forces with LEONARDO - FINMECCANICA - AIRCRAFT DIVISION in order to design an advanced device for noise control, which will be installed on a turboprop aircraft of new generation [26]. Results of evaluation: $\mathrm{TRL}=6, \mathrm{CRL}=2$.

Adaptation of $U$ - shaped tail section. Within program Clean Sky advanced shapes of U-tail section were researched in order to reduce acoustic emission of the aircraft at take-off and landing. Experimental researches were conducted in an air tunnel to confirm the results of numerical modelling [27]. Results of evaluation: $\mathrm{TRL}=7, \mathrm{CRL}=2$. 
Projects of Russia. Fan of engine PD-14. Engine PD-14 of the fifth generation is developed in wide cooperation with companies of United Engine Corporation [28]. The engine fan has hollow wide-chord titanium blades designed with regard to aerodynamic and acoustic characteristics. Results of evaluation: $T R L=9, C R L=8$.

Fan with raked blades of the outlet straightener. The researches are conducted by numerical calculation and experimentally by model C-3A [29]. Results of evaluation: $T R L=3$, $\mathrm{CRL}=2$.

Combined noise suppressor (SAS) is a rather efficient method to reduce noise. One of the solutions offered is a combined noise suppressor designed by CIAM [30]. Results of evaluation: $\mathrm{TRL}=3, \mathrm{CRL}=2$.

Integration of new generation power plant (PP) and an airframe of an advanced A/C. It's apparent that the projects, focused on integration of $\mathrm{A} / \mathrm{C}$ airframe and $\mathrm{PP}$ with a target function of minimization of acoustic emission, are actual ones for all aviation organizations, which make products of aviation equipment. For instance the most important field of work of CIAM specialists is a parameter optimization of PP of A/C for various purposes and various flight speeds by the optimality criteria: flight characteristics, fuel efficiency, carrier cost, life cycle hour cost and environmental characteristics [31]. Results of evaluation: $\mathrm{TRL}=2, \mathrm{CRL}=2$.

Use of micro-jets in a supersonic under-expanded jet. Experimentally it was found out that in case of supersonic under-expanded jet the noise level decreases essentially in the lowfrequency region of the spectrum and a slight increase takes place at high frequencies. Use of micro-jet technology makes it possible to reduce the total noise level of a jet by 2-3.5 dB uniformly in the whole range of angles [32].

Results of evaluation: $T R L=3, C R L=1$.

The results of the analysis of TRL/CRL technologies are presented in table 1.

Table 1. The results of the analysis of TRL/CRL technologies.

\begin{tabular}{|c|l|c|c|}
\hline № & \multicolumn{1}{|c|}{ Technologies } & TRL & CRL \\
\hline 1 & Fan for engine Company Pratt \& Whitney (1st Generation) & 9 & 9 \\
\hline 2 & Fan for engine series GEnx & 9 & 9 \\
\hline 3 & Fan of engine PD-14 & 9 & 8 \\
\hline 4 & Composite fan blade (Rolls-Royce) & 8 & 4 \\
\hline 5 & Fan for engine Company Pratt \& Whitney (2nd Generation) & 7 & 4 \\
\hline 6 & Propfan OPEN ROTOR & 7 & 4 \\
\hline 7 & Fan blade designed by SAFRAN & 7 & 4 \\
\hline 8 & Adaptation of U - shaped tail section & 7 & 2 \\
\hline 9 & A device for reducing noise in the cabin of turboprop aircraft & 6 & 2 \\
\hline 10 & Sound absorbing structure (SAS) with 3D spiral cell of Safran Nacelles & 3 & 2 \\
\hline 11 & Fan with raked blades of the outlet straightener & 3 & 2 \\
\hline 12 & Combined noise suppressor & 3 & 2 \\
\hline 13 & Use of micro-jets in a supersonic under-expanded jet & 3 & 1 \\
\hline 14 & Fan blade with blowing out extra air mass into aerodynamic wake & 3 & 1 \\
\hline 15 & Integration of new generation PP and A/C & 2 & 2 \\
\hline
\end{tabular}

Priority research areas in aviation for environmental improvement: reduction of specific fuel consumption by 17-25\% (compared to the engines designed in 2010); ensuring a margin of $55-65 \%$ as for $\mathrm{NO}_{\mathrm{x}}$ emission level relatively to the allowances of CAEP6 ICAO; reduction of noise level up to 25-30 EPN dB related to allowances of Chapter 4 ICAO. 
Experts deem that all engines of the 6th generation will be electrical ones, that is to say without air bleeding from the engine passage, and with electric drive actuators, startergenerator on the shaft of high-pressure spool and generator on low-pressure spool, with intelligent ACS combined with the diagnostic system, which provides technical condition monitoring and account of usable service life.

This work was supported by the project PARE - Perspectives for Aeronautical Research in Europe. This project has received funding from the European Union's Horizon 2020 research and innovation programme under grant agreement No 769220.

\section{Conclusions}

The review on development trends of the noise reduction methods in air engines by models TRL/CRL showed that technological advance in this field will make possible to reduce tonal noise and broad-band noise.

On the grounds of analytical evaluation it can be claimed that for the near-term outlook (till 2025) the technologies reviewed are characterized by the readiness levels $T R L=6 \ldots 9$ and $\mathrm{CRL}=4 \ldots$.. For the long-term outlook (till 2035) $-\mathrm{TRL}=2 \ldots 3$ and $\mathrm{CRL}=1 \ldots 2$.

The aim of program ACARE Flightpath 2050 (goal 9) can be achieved by deep inculcation of the projects focused on:

- $\quad$ research of the rational design for the fan reduction gear;

- $\quad$ mastering the modelling technique of operating processes of $\mathrm{PP}$ engine and $\mathrm{A} / \mathrm{C}$;

- $\quad$ acoustic and aerodynamic perfection of the fan blade shape;

- $\quad$ research of control over the boundary layer methods;

- $\quad$ employment of composite material;

- $\quad$ the use of more effective sound-absorbing structures;

- $\quad$ further acoustic perfection of OPEN ROTOR engines;

- integration of advanced $\mathrm{A} / \mathrm{C}$ airframe and PP of new generation with the target function to minimize acoustic emission of the aircraft;

- $\quad$ research of active control over acoustic characteristics of the jet by micro-jets and combining of noise active control with employment of chevron nozzles;

- $\quad$ reduction of inner sources noise - compressor and air bleed valves, combustion chamber and turbine.

Moreover the solution of noise reduction problems will depend on development of "electrical aircraft" projects.

\section{References}

1. J. I. Hileman, T. G. Reynolds, E. R. Blanco, Th. R. Law, S. Thomas, 45th AIAA Aerospace Sciences Meeting and Exhibit Special Session - Towards A Silent Aircraft (2007)

2. А. Ф. Чевагин, Всероссийская научно-техническая конференция Авиадвигатели XXI века, ЦИАМ имени П.И. Баранова (2015)

3. Future of Europe (https://ec.europa.eu/ commission/future-europe_en, accessed 26 May 2018)

4. G. Kröger, R. Schnell, N. D. Humphreys, ASME Turbo Expo 2012: Turbine Technical Conference and Exposition (2014)

5. C. Polacsek, R. Barrier, M. Kohlhaas, T. Carolus, P. Kausche, A. Moreau, F. Kennepohl, AerospaceLab Journal, 7, AL07-03 (2014) 
6. Л. А. Рыбинская, Р. В. Бульбович, В. И. Кычкин, Вестник ПНИПУ. Аэрокосмическая техника, 48, 104-118 (2017)

7. Ch. A. Perullo, J. C. M. Tai, D. N. Mavris, Journal of Engineering for Gas Turbines and Power, 135, 071204 (2013)

8. E. S. Hendricks, M. T. Tong, 48th AIAA/ASME/SAE/ASEE Joint Propulsion Conference \& Exibit (2012)

9. F. Danner, C. Kendall-Torry, ASME Turbo Expo 2014, V02AT41A014 (2014)

10. ACARE (http://www.acare4europe.org/sria/flightpath-2050-goals, accessed 25 May 2018)

11. Next-generation innovation (https://www.geaviation.com/military/engines/ge-adaptivecycle-engine)

12. Разработка США технологий создания двигателей шестого поколения для боевой авиации (http://engine.aviaport.ru/issues/94/pics/pg02.pdf)

13. Е. V. Jalovenko, V. N. Zhuravlev, Технологические системы, 4 (85), 55-60 (2018)

14. В. Н. Журавлев, Авиационно-космическая техника и технология, 7, 48-55 (2018)

15. C. Nae, INCAS BULLETIN, 6 (1), 99 - 110 (2014)

16. J. Szodruch, W. Grimme, F. Blumrich, R. Schmid, Journal of Air Transport Management, 17, 33-39 (2011)

17. E. Baharozu, G. Soykan, M. B. Ozerdem, Energy, 140 (2), 1368-1377 (2017)

18. А. М. Хаматханова, Экономика науки, 2(1), 23-34 (2016)

19. В. А. Антонец, Н. В. Нечаева (http://www.unn.ru/pages/e-library/aids/2007/90.pdf)

20. https://aeronautica.online/2017/10/13/pratt-whitney-ends-next-generation-gearedturbofan-technology-testing/

21. https://aeronautica.online/engines/general-electric-genx/

22. https://www.rolls-royce.com/innovation/advance-and-ultrafan.aspx\#background

23. https://www.cam.ac.uk/research/news/silent-flights-how-owls-could-help-make-windturbines-and-planes-quieter

24. M. Versaevel, L. Moreau, E. Lacouture, Greener Aviation Conference, ID 23 (2016)

25. M. Kohlhaas, T. H. Carolus, ASME Turbo Expo 2014, V02AT41A002 (2014)

26. M. Arena, A. De Fenza, M. Di Giulio, A. Paonessa, F. Amoroso, Greener Aviation Conference, ID 186 (2016)

27. Ph. Rostand, Greener Aviation Conference, ID 175 (2016)

28. http://expert.ru/ural/2018/24/pd-14---glavnyij-proekt-rossijskogo-dvigatelestroeniya/

29. A. A. Rossikhin, S. V. Pankov, Yu. D. Khaletskiy, V. I. Mileshin, ASME Turbo Expo 2014, V02AT41A006 (2014)

30. Ю. Д. Халецкий, Акустический журнал, 58, 4, 556-562 (2012)

31. ЦИАМ. Авиационное двигателестроение: день вчерашний, сегодняшний и завтрашний (http://www.ciam.ru/research/engines/aviation/ ?PAGEN_1=2)

32. Д. А. Губанов, Влияние микроструй и акустическое излучение сверхзвуковой недорасширеной струи (дис. канд. физ.-мат. наук: 01.02.05, 2014) 